\title{
A Perspective of Cultural Change in Korea and Its Effect on Multicultural Children
}

\author{
Francis Brannen, Debra MacLellan \\ Department of General Studies, Sangmyung University, Seoul, Republic of Korea \\ College English Department, Yonsei University, Seoul, Republic of Korea.
}

\begin{abstract}
This paper is focusing on children in multicultural families. Some research has been conducted on migrants workers, their needs and evaluations, foreign brides, and mixed Koreans and the impact on these people, but little research has been conducted on the outcomes, needs, options, and effects of children of multicultural families here in Korea. Currently in Korea, there are over seven multicultural schools that enroll Amerasian Children; one Korean parent and one American parent, Damunhwa; one parent of Korean ethnicity and one parent of another country, and children of migrant workers. Our research was conducted in an Amerasian school in South Korea. The subject of education has been a sensitive topic both for ethnic Korean students and children of multicultural families. Multicultural children who attend Korean public schools often suffer from racial abuse, bullying, and exclusion. These children have trouble adapting to the Korean educational culture and encounter many barriers trying to adjust and conform. Many are discriminated against; suffer numerous forms of abuse, both physically and emotionally. Some say an educational alternative for multicultural students is providing separate schools for them. This brings many disadvantages for the students' integration into Korean society. The paper examines current initiatives in place regarding school policy and education, delves into the deeper effects on multicultural children and offers their perspectives of living in Korean society as well as offering solutions.
\end{abstract}

Keywords: multicultural education, discrimination, education policy, effects, integration, organizations

\section{Introduction}

It is a well known perception that Korea is a nation based on shared genetic ancestry and blood. Korea has a long history of homogeneity propaganda since the liberation for colonial rule and the IMF crisis of the 1990 's. It was this propaganda that helped unite Koreans and it was one of the primary factors that helped them to overcome their struggles during these hard times. While this may be understandable, this strong nationalism does not leave room for much flexibility, adaptability, and uniqueness. The very phenomenon that has made Korea so strong and helped Korea overcome so many obstacles, now is the very thing that is holding them back when trying to live in this global society. Koreans still have a strong sense of pride and a deep rooted sense of what it means to be Korean and many carry biases towards multiculturalism that have skewed their perceptions. Being different in appearance and culture, Koreans sensed this as threats against their homogeneous society. As a result, it is very difficult for foreigners to integrate into Korean society because of the lack of language skills and an often hostile or closed attitude towards foreigners. "Today, South Korea remains over 97 per cent Korean and is one of the most homogenous countries in the world" (International Organization for Migration, 2013). As Korea becomes more globalized, attitudes are changing, but there is still a long way to go for foreigners to escape the mentality of this homogenous society.

According to OECD, the International Migration Outlook (2013), there are 1,232,200 foreign citizens from 184 countries classified as long term residents, which accounts for $2.3 \%$ of Korea's total population. According to the Korea International Labor Foundation, it was estimated that in 2013, 62,000 workers came to Korea which is an increase of 5,000 laborers since 2012 (March, 2013). The Korean government wants to expand the quota for foreign migrant workers to relieve industrial shortages and improve economic vitality. In addition, the number of foreigners marrying in rural families are on the rise. Many Korean men in the countryside have foreign brides and the number of foreigners married to Koreans from 2008 to 2011 has increased by almost $50 \%$ to 211,458 . As a consequence, the number of children from multicultural backgrounds aged 6-18 has more than tripled and children born into multicultural families today, a family consisting of a parent from one or more cultures, has also grown from 44,258 in 2007 to 151,154 in 2010 (Korean Ministry of Public Administration and Security, 2013) .

Overall, the number of foreigners staying in Korea has increased significantly and some demographic groups representing this shift are Korean Chinese who moved back to their ancestral homeland, Americans, Vietnamese, and Japanese. They include migrant workers, marriage immigrants, children born to multicultural families, Korean nationals returning from abroad, and even North Korean defectors (Korea.net, May 8, 2012). 
Korea is going multicultural and there seems to be a paradigm shift but are Koreans ready for this fundamentally new concept?

Korea is starting to recognize multicultural families and the members in these families have been starting to expand their roles in Korean society. However, despite this steep rise, the perceptions of many Koreans towards them have not caught up. "Koreans do not accept them as real Koreans", according to Yoon Pyung-joong, a philosphy professor at Kangwan National University (Kim, Y.W, April 12, 2013). Why does Korean society struggle to embrace multiculturalism? Why do children of multicultural families still face discrimination despite efforts from the government, teachers and the civil society?

According to the National Human Rights Commission Korea, $42 \%$ of students from multicultural families were taunted by classmates in a 2010 survey. (NHRCK, 2010). The survey by Seoul City showed that four of five teenagers were not in school, largely because of discrimination and bullying. In that same survey, $26.7 \%$ of immigrant children responded that they felt a strong urge to quit school when Korean students looked down on them just because they were considered as foreigners. In addition, the Ministry of Education, Science and Technology and the Ministry of Justice in South Korea report that 7 out of 10 immigrant children are not attending middle schools or high schools and only 948 children out of the 3034 school age children reported in 2011 went to schools that received formal education. ( Park, J., July 2, 2012). According to the study conducted by the Ministry of Gender Equality and Family (MOGEF), 41.3 percent of multicultural families in Korea said that they had experienced discrimination in 2012, up from 36.4 in 2009 (Kang, T.J., August 20, 2013, The Diplomat). People are judged based on their skin color, where they are from, and the wealth of their home country. There is little assimilation into Korean society and little respect for differences. There has been a long history of resistance.

The system in Korea is not working because there is still a resistance to foreign workers being here. Jasmine Lee, the first non-ethnic Korean member of parliament says that the government needs to do more to teach Koreans about accepting multiculturalism. She is just one person to experience the prejudices first hand. After being elected, she received much backlash and was a target of a racist online campaign questioning her right to live in Korea. Some Koreans feel you have to do something special for the country to be able to live here or be recognized as an important contributor to Korean society. Famous sports players or even coaches like Gus Hindink who coached the 2002 World Cup Soccer Korean National team or Brian Orser who coached, Kim Yuna to a gold medal in the Olympics, received keys to the city. Amerasian football player, Hines Ward, half black and half Korean, was only recognized when his team won the Superbowl. What about foreign workers here? There is not much recognition for these people serving to help the Korean economy or their contributions to society. Migrant workers alone account for over 714,169 of the foreign working population (Ministry of Justice, December, 2011). A government survey of 2,500 people showed only $36 \%$ welcomed immigrants(Oaten, J., November 23, 2012).

Where do these ideas stem from? The characteristics of culture are that it is a learned behavior, it is shared and it is an adaptation. According to Professor Tun Myint from Yongon University in Myanmar, culture is manifested through an infinite number of ways through social institutions, lived experiences and the individuals' fulfillment of psychological and basic needs. It is primarily manifested through our values, our non-verbal communication and our language (Paving the Future of Multicultural Asia, May 27-29, 2013 Seoul, Korea). Korean society is ethnocentric which means there is an inability to view other cultures as equally viable alternatives. They see their society as normal and superior. To overcome this ethnocentric thinking, Koreans need to learn to become more aware of diversity and acquire more understanding of how to function in multiple cultural groups. Cultural competence is exactly what Korea needs to become more informed to make competent decisions in education, social policy and health care for multicultural families. Services need to be adapted and integration into society is a must.

We cannot deny the arguments that there are some drawbacks of multiculturalism in any society. Countries can feel like they are losing their national identity, citizens may feel like they are losing their traditions and culture, and some may argue that it increases unemployment or multicultural families are a burden on society. If Korea wants to truly be a multicultural society, they have to leave the notion of a homogeneous society, tear down the walls of segregation and prejudice, and start to embrace the diversity of its people so that it can flourish in a global world and build a dynamic, diverse Korean society. There is a fine balance with maintaining one's own heritage, culture and language and then trying to integrate and adopt a new one. The concept of blending the cultures into a melting pot should be looked at from a different perspective, like a box of chocolates. Like various chocolates in one box, integrating all cultures in their uniqueness under one society should be encouraged. 


\section{Educational Policy and Practice \\ The School System for Multicultural Children}

Children of multicultural families are really affected in terms of their educational growth. Questions we asked ourselves were numerous. Are there educational opportunities for multicultural children? What options are currently available for the children of multicultural families, and are these programs sufficient and up to the standards of the national system? What happens to students who are not accepted into society? What is the government doing to help? Are there solutions to some of the dilemmas multicultural students face when it comes to their educational growth?

According to the Korean National Constitution, Article 3, all children in Korea have the right to a free education up to middle school. (Korean National Constitution, 1948). With the recommendation of the Human Rights Commission of Korea, in 2010, migrant children's access to public education and teaching of Korean language in the public education system must be improved. (NHRCK, 2010). All children aged 6-15 have the right to a free education regardless of ethnic background and no child is to be refused because of ethnic makeup or lack of documentation. Children of migrant workers can be undocumented in Korea. The Korean government does not allow an immigrant born in Korea to claim Korean citizenship and many children of migrant workers cannot claim their parents' country as well due to their parents working in Korea illegally. As a result, these children reside in Korea with no documentation at all from any country. The Korean government has recently recognized the need for reform for these children, so they have announced that all children whether documented or not, can attend Korean public schools.

There are problems with this policy. Even though multicultural children are allowed to enter a public school, it is inevitably up to the principal to accept or deny these students. The law and the reality of acceptance differ greatly. Ms. Ra Lee, a member of the regional council in Korea has said the government has ordered all schools to accept all children whether documented or not. However, schools are reluctant to accept multicultural students especially if the teachers in that school are against it and the students are reluctant. Ms. Ra Lee says the current laws are ineffective. (Paving the Future of Multicultural Asia Conference, May 27-29, 2013, Seoul, Korea). Many teachers and schools are not equipped in how to handle multicultural children and even the school curriculum does not offer teacher training in this field. As a result, many children of multicultural families are left to limited options.

Students from multicultural backgrounds sometimes have difficulty with the Korean language, which affects their performance at school. Around $40 \%$ in a survey said they need Korean language education and assistance in basic subjects. (National Human Rights Commission, 2010). One reason the system of putting children in publics schools is not working is because students don't have enough Korean language background to keep up with their ethnic Korean counterparts. Before they even begin, they are already behind. Teachers are not trained to effectively deal with children of another culture or language and are not specifically trained in multiculturalism themselves. Often students feel alienated from their peers, are ostracized and humiliated and even labeled with learning disorders.

The government has recognized the lack of formal Korean language training and as of March 2013, the Education Ministry unveiled a set of policies to help children from multicultural families adapt to the Korean school system. The Education Ministry plans to increase the number of preparatory schools from 3 to 36 nationwide during the 2014 school year. The schools will teach Korean language and culture before students enter a regular school. (Kim, Y.W., April 12, 2013). According to the Education Ministry, there are 38,678 such students in primary and secondary schools, accounting for $0.55 \%$ of the total enrollment as of 2011 . The Ministry of Education expects the percentage to reach 1.12\% in two years . (Lee, W.Y., March 13, 2012). There are a number of support centers out there; 23 in Seoul and 201 nationwide focusing on child education and relationship counseling among family members. On January 27th, 2012, the South Korean government announced a plan to help more foreigners residing here. "The plan shows that the government is keen on bringing foreign workers to meet the needs of business, run multicultural classes to effectively help foreigners settle in Korea, and have more schools provide courses on multiculturalism." (Korea.net, May 8, 2012).

There are a few schools that are springing up in Korea for children from multicultural homes. These designated schools are designed to help these children of ethnic minorities adjust to Korean society and help them obtain an education. Korean children of multicultural families are treated differently; they are treated almost separately from mainstream society. There are both positives and negatives from multicultural children attending separate schools. In these schools. the teachers can be trained in diversity and multiculturalism or they may not be. One essential benefit is that these schools provide an adequate amount of support for these children that would be almost non-existent in the regular public school system. Most multicultural schools in Korea are predominantly taught in Korean, so students do have the advantage of eventually merging with other students from public schools. The negative side is segregation. These students have little opportunity to mix with other children from public schools and as a result, this limits their assimilation into the society. 
This idea of separate but equal seems to make the youth torn on identity. Most who are born to a multicultural family and live in a country most of their lives feel a belonging to that country, yet still face discrimination from that very same country. The purpose of these schools originally was to bridge the gap the students would normally feel attending a public Korean school. However, there is often a disconnect from regular society. These schools do not necessarily help students to adjust to the mainstream society and the culture. This is an evident problem in Hong Kong where policy changed in 2006 initiating separate schools. Yang (2013) says that Hong Kong has struggled with its ethnic minorities for some time. He notes, "Because of the poor quality of education in these schools, they end up not being able to read and write in Chinese" and "their inability to learn the language affects their education opportunities and, subsequently, their employment" (Yang, C., March 10, 2013). If we compare the system in Hong Kong to Korea, we may speculate some similarities.

Language and employment are strong concerns for multicultural families. One of the first established multicultural schools in Korea has a curriculum only taught in English. Other schools for multicultural children are taught predominantly in Korean. This is one advantage that Korea has over schools in Hong Kong. Most multicultural children do have the opportunity to learn and immerse themselves in Korean in public schools and some multicultural schools. However, even though these students may get extra attention in the native language in multicultural schools, they are often brought up with another language, and the transition of learning Korean could set these students behind ethnic Korean children who attend a public school. These students are not only learning new curriculum but doing it in an unfamiliar language. Students could do well and could be very bright but they may fall behind what the regular course requirements are for students of their age and grade. Korea is an extremely competitive society when it comes to education, and it's the survival of the fittest. Multicultural students may not meet the specific requirements due to this factor and may lose opportunities as a result. Another important factor to consider is the amount of money spent on private education. Most migrant workers are not compensated enough or have the extra finances to provide their children with these extra services of private teachers or schools. The students may receive an adequate education at some schools, but the separate but equal phenomenon may not provide these minority Koreans with the same opportunities.

Some multicultural schools in Korea are classified as accredited while others are not. The ones that are accredited have to follow the Korean public school curriculum. Some multicultural students have attended Korean public schools their whole lives and speak fluent Korean. However, there are some serious problems with multicultural students upon graduation. If the student does not have Korean citizenship but has been raised in Korea all of his or her life, the student still cannot attend a Korean university or can only attend a Korean university as an international student. It is devastating to think that these children, born, raised and educated here in Korea, do not have the right to attend local universities. What's more devastating, is that for these children, Korea and Korean language is all they know. As a result, students do not enter university and struggle to obtain employment because of the lack of having a degree. There are several discrepancies in what's acceptable and what's denied for these children and the future education of multicultural children, scholastically, face many barriers. Basically, if the government allowed for children born in Korea to become citizens, this would alleviate much of the disparity and gap between children of multicultural families and their ethnic Korean counterparts.

\section{Are Koreans Prepared?}

It is predicted that one in five families will be multicultural in 2020 . In an interview conducted by James Oaten from The World Today in 2012, Ms Jasmine Lee, a member of the National Assembly said ,"the government is actually very unprepared for the fast rise of the immigrants in the country" (November 23, 2012).With the large number of foreigners entering the country and the continuing rise of foreigners coming into Korea this year alone, this is going to cause havoc in many parts of society such as health and Medicare, education, transportation, security, and even the legal justice system. If programs are not supported and implemented soon, Korea will not be able to handle the vast amount of concerns foreigners will have. There is a tendency to ignore what is currently happening and the failure to recognize the vast influx will be detrimental to Korea's future economic stability.

Most funding for programs for multicultural families is through donations, non profit or volunteer organizations, and religious groups. It is these civic groups that have helped to lay the foundation for this emphasis on multiculturalism. Local municipalities have no clearly defined policy to follow and public officials lack the expertise in supervising these tasks (Yang, 2012). More training is needed both in the school systems as well as the government. Korea is only now being recognized as a multicultural society and they face many challenges because of their short history and experience with this. The positive aspect is that there is a rapid increase of offices and departments managing these new policies. However, the problem lies in the training of the employees when it comes to multiculturalism. Training is crucial for heads of all government organizations, local municipalities and public officials in order to enhance and strengthen the programs already in place. This 
is also true for education in multiculturalism, as teachers are not equipped on how to deal with multicultural children, very little programs in teacher training courses focus on this concept of multiculturalism and most schools shy away from the things they don't understand or are not trained to handle.

The Korean government has been steadily working on programs for multicultural families and currently there is an overabundance of measures and programs. While the need is being recognized, the problem lies in the fact that there are so many, and because there are so many, they are not effective long term solutions and only provide short term relief. Professor Yang says these programs fail because "there is a lack of governance between all parties, an overlapping of tasks and budgets and a disconnect between foreign residents and programs...."(2012).

\section{Effects On Children}

People are discriminated against everyday based on their race, skin color, ethnicity, and so on. Korea, a country which prides itself on its homogeneous and racially distinctive culture, does not see others who may look different as Korean. In Korea, many multicultural families and their children suffer as a result, and it is these people who must deal with the side effects of this one sided thinking. Although some of these families may be Korean on paper, there is still racial discrimination based on other languages spoken or even the darker the skin. Children often experience identity problems, have trouble adjusting in school, and as these children progress in age, experience higher dropout rates and less opportunity for educational progress. To acquire firsthand knowledge and feelings from the students themselves, we conducted surveys at a multicultural school in Korea. Sentiments expressed are the views of the students only and reflect the current social norms.

When multicultural schools were approached with the survey, there were mixed reactions from the schools' staff. Two non-government sponsored multicultural schools, were very hospitable toward giving the survey out to the students. However, one school which has two campuses, the principal refused to allow the survey based on his view that the students were weary of answering questions about their life in Korea. Paradoxically though, these same students were forced to be filmed on a Korean TV show a few days later. The questions on the survey asked some basic demographics such as age, grade, gender and ethnicity (refer to Appendix A). It is important to note that the populations in these multicultural schools are low and the enrollments in the grades vary. The surveys conducted were based on high school students only. The data in the figures below are based on the school in Dongduchon. The multicultural school only had thirteen students, nine female and four males, from an age group ranging from thirteen to seventeen. The ethnicities of the students varied from Korean American and Mixed Korean.

4.1 Statistics from the Multicultural School Surveyed

Figure 1: Would you like to attend a Korean public school?

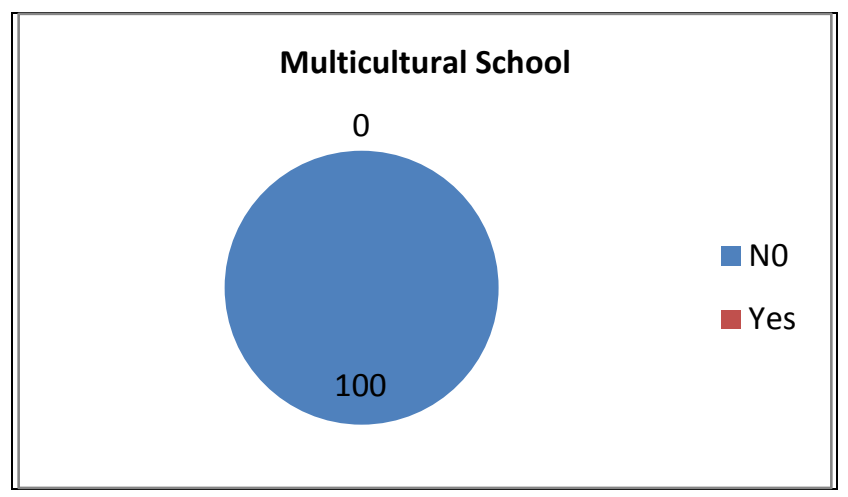

Survey of Multicultural School Students 
Figure 2: Have you ever attended a Korean Public School?

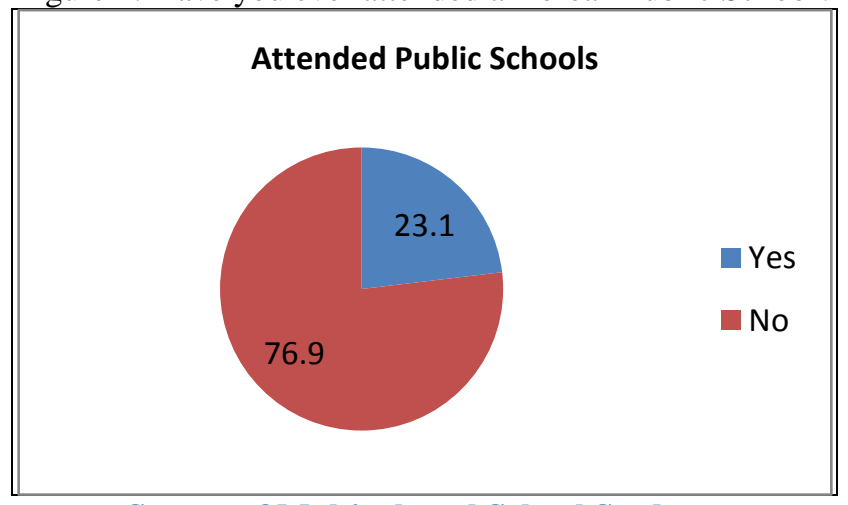

Survey of Multicultural School Students

Figure 2 A: If yes, how well were you treated by other students?

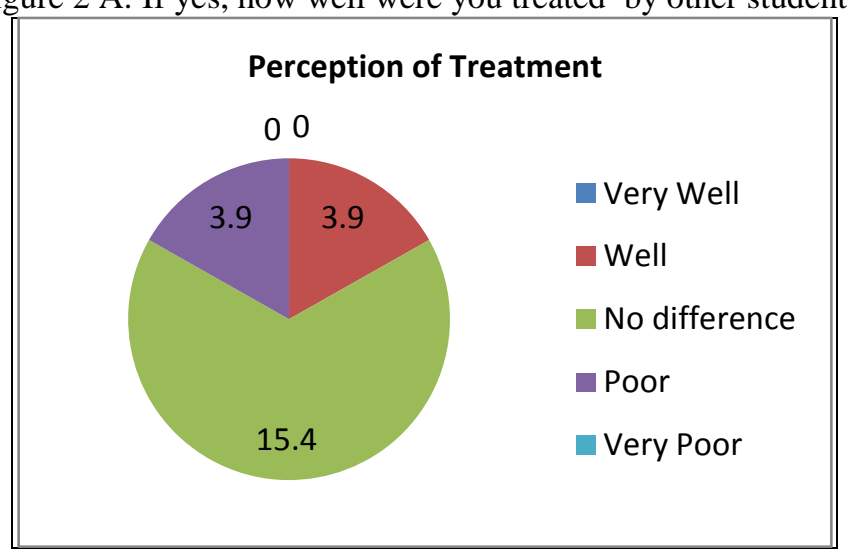

Survey of Multicultural School Students

Figure 3: How long have you lived in Korea?

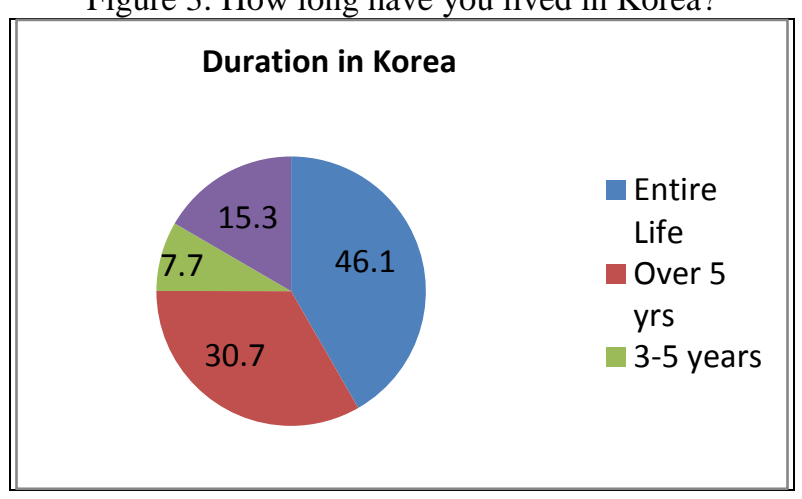

Survey of Multicultural School Students

Figure 4: What languages do you speak? 


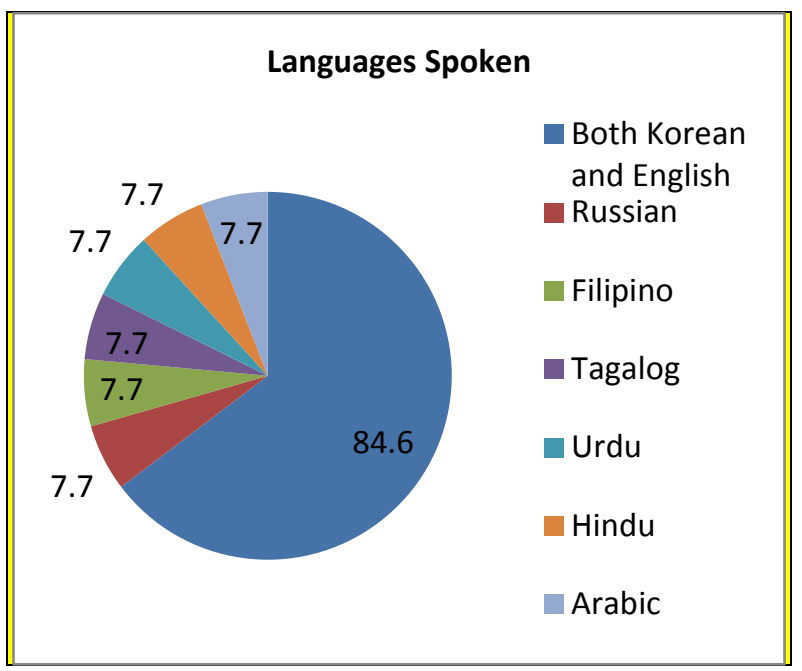

Survey of Multicultural School Students

Note: All but two students spoke both Korean and English as well as an additional language.

Figure 5: What is your definition of what is to be Korean?

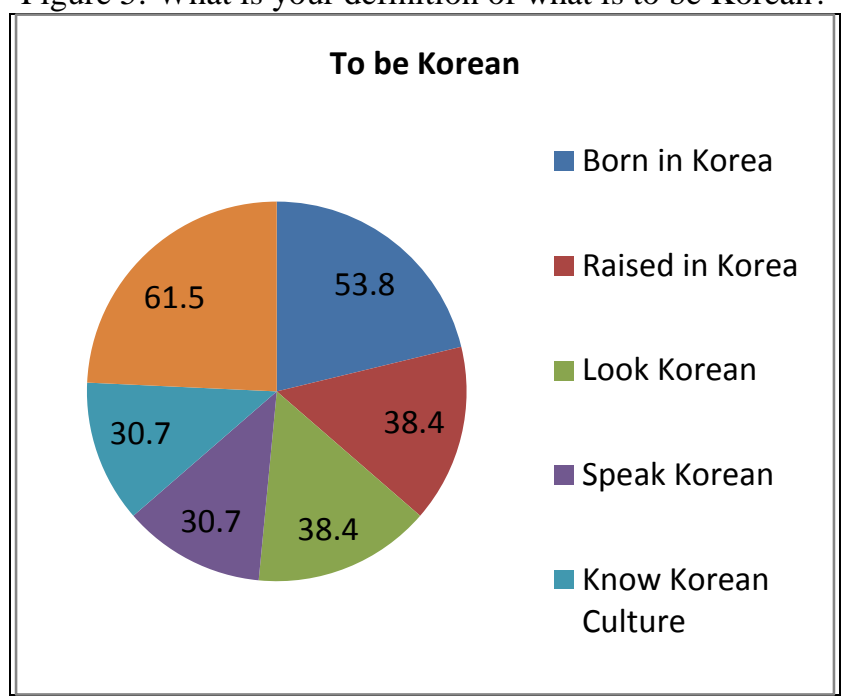

Survey of Multicultural School Students

Note: Students checked more than one answer.

Figure 6: What problems do multicultural children face in Korea?

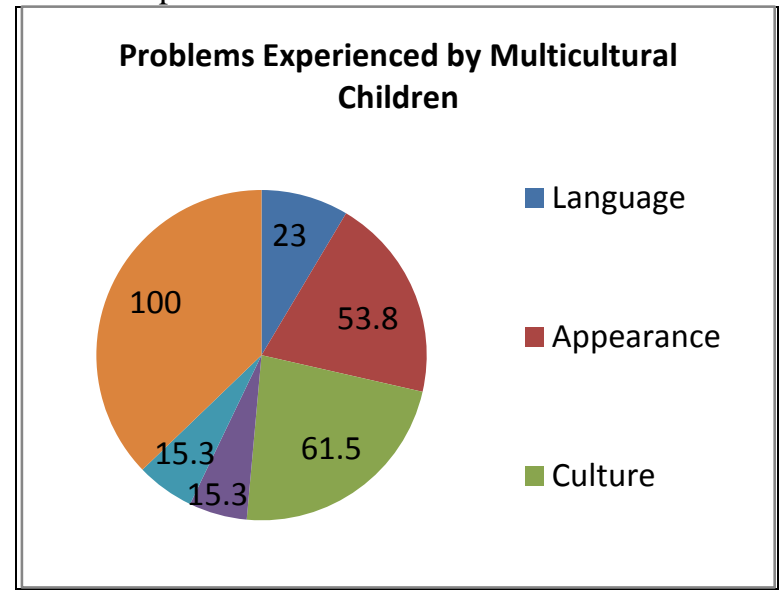

Survey of Multicultural School Students

Note: Students checked more than one answer. 
The first question for the survey was, "Would you like to attend a Korean public school?" All students at the multicultural school stated no. Though there wasn't a question asking why, the students do attend a Christian school and the classes are taught in English with an American style curriculum. The second question, "Have you ever attended a Korean public school?" Only three students stated yes, and of the three students, two students are of mixed background, one being Korean/Pakistani, and the other student being Korean/Indian. Those that answered yes had two follow up questions. If yes, "How were you treated by other students?" Two students stated no difference and the Korean/Pakistani student responded with poor. The second follow-up question, "How were you treated by the staff and teachers at your school?" One student stated no difference, one stated well and the other student stated very poor. When asked, "Do you think multicultural students should attend Korean public schools?" All but one student stated no. When asked, "Do you feel comfortable living in Korea?" All but one student stated yes. When asked, "Have you ever experienced discrimination? "All students answered yes except one student who is Korean-American.

Of the students surveyed, five students have lived in Korea their entire life, four students have lived in Korea for over five years, one student 3-5 years and two students have been in Korea for 1-3 years. In terms of language abilities, all students speak both Korean and English except for two students, one of Russian/American background and the other student of Filipino background. Other languages listed selected by the students were Tagalog, Urdu, Russian, Arabic, and Hindi.

When it comes to identity, the students were asked, "Which of the following matches your definition of what it means to be Korean?"(Refer to Appendix A).Seven students responded to 'born in Korea', five responded to 'raised in Korea,' five responded to 'look Korean', four responded to 'speak Korean', four responded to 'know Korean culture' and eight responded to 'have Korean parents.'

The final question of the survey asked the students to select, "What problems do multicultural children face when living in Korea?" The students were allowed to choose all answers that mattered to them. Three students selected language, appearance was selected by seven, culture was selected by eight, and peer pressure by two students. Three students selected socio-economic background and all students also selected stereotypes.

\section{Our Analysis and Results}

After reviewing the surveys of the multicultural school students, it is not surprising to see similarities in their views towards living in Korea. As the survey population was limited in numbers, we can only speculate on the results from a larger population. M.A.C.K. (Movement for the Advancement of Cultural Diversity in Korea), have also conducted some informal cultural awareness training sessions in public schools and it is important to note that these students also demonstrated the need for more awareness of multiculturalism. With more education and assimilation, more cultural training and exposure, both groups of children can help to change the attitudes in the future to a more tolerable, accepting, and integrated, multicultural society.

\section{Organizations That Work With Multicultural Children in Korea}

Though there are organizations focused on multiculturalism in Korea, few have focused on the education system and the students themselves. The Movement for the Advancement of Cultural-diversity of Koreans (M.A.C.K. Foundation), has organized student centered activities through volunteer established programs to assist students in their academic work. Subject classes such as Korean, art, and sciences are taught by volunteers reaching out to multicultural students. The Foundation's mentoring program has also helped to develop the students' positive feelings towards their surroundings and awareness about the world around them. Mentoring programs involve learning about students in other countries, attending sporting events and meeting professional athletes of multicultural backgrounds, leadership and team building, and cultural exchanges. A unique aspect of working with the students is to share and help them build confidence in knowing that there are people out there to stand next to them and support them. Sympathy is not welcomed, nor used in the Amerasian Christian Academy or Asia Community School in Busan.

\section{Vll. Conferences and Forums Held (2013)}

More and more conferences are being conducted to promote the social awareness of multiculturalism in Korea. "Bring Your I.D." a forum held at Yonsei University on May 18, 2013 in Seoul, had speakers who were of different Korean ethnic makeup. The conference sponsored by A.S.K., Adoptee Solidarity in Korea and M.A.C.K., Movement for the Advancement of Cultural-diversity in Korea, offered interesting perspectives of what it meant to be multicultural and the issues that are faced by some multicultural children here and abroad. The event was moderated by Peter Bint, a reporter and radio host in Korea and T.V. persona.

The issues discussed by the panel of mixed Koreans are real issues for multicultural and mixed children here in Korea. Children are faced with an identity crisis. Children of multicultural families are trying to adapt to the new culture of Korea, yet, at the same time, trying to hold on to or maintain their own culture from their homelands. Other children of mixed Korean descent do not view themselves as Korean at all except for 
appearance. They feel they are a representation of the culture, values and traditions of their homelands. Some children feel fake in their identity because they look Korean on the outside, but are not Korean on the inside in terms of the culture, thinking, and values. Many children of multicultural families are searching for avenues to express their identity. Some do this in a positive way, adopting and learning about the new culture and others use defense mechanisms as coping skills. Many of the speakers on the panel said that stereotyping and discrimination can often shatter a young child and have serious consequences. Accepting their own identities is one thing but having the society accept you is another thing. Gregory Chan-Wook Diggs Yang, Chairman of the M.A.C.K. Foundation said, "It's hard to tell someone their identity. If you choose your own identity, then society should be set up so that you can go into that society. There is still that boundary" (Bring Your I.D., May 18th,2013).

An even larger forum took place on May 27, 2013, and this was the 1st ever international conference in Asia on multiculturalism. The event, "Paving the Future on Multicultural Asia", contained numerous speakers from around the globe. This was a three day conference that the government of Korea had sponsored and well known Congresswoman Jasmin Lee, a naturalized Korean, gave the keynote address. There were various sessions with a diversity of topics ranging from the social effects of immigrants in Korea, the socio-cultural aspect of migration, women and migration, stereotypes, social policy, migrant workers, health, education and welfare among many others. Yuko Kitada, a United Nations public officer, focused on the multicultural society for the benefit of youths. She classes a multicultural society as, one having a diversity of languages, beliefs, values, lifestyles, career paths, communication styles, and many different common senses. She said that a failure in one value system does not have to be a failure in another and that our youth do not need to conform to one model of success. In a multi-value society, there are many forms of success and she says that all talents can find their places in society. She talked about children finding their own individuality and the importance for them to find out who they are. Ms. Kitada says a multicultural society allows for youths to find their own places and allows all people to be inspired and be creative in their own lives. This conference suggested the value of keeping dialogue open and as Ms. Kitada stated, there is a role for everyone to play and we all need to challenge ourselves to make change rather than challenging others (Paving the Future on Multicultural Asia, May, 27, 2013).

\section{Need for Integration, Policy Change and Funding}

Korea's multicultural policies have undergone trial and error with many laws and institutions established within a short period of time. Professor Yang Ki-Ho, from Sungkonghoe University and former president for the Korean Association for Multicultural studies, describes some of these policies that were created. These include the August 2004 implementation of the Employment Permit System, the May 2006 establishment of the Foreigner Policy Committee, the ordinances set in place by local municipalities since 2007, and the March 2008 enactment of the Support for Multicultural Families Act. Significant accomplishments have been made but there still is a lack of consensus and support from local municipalities, private companies, and civil society says Professor Yang (Yang, K., January 18, 2012, International Symposium). The problem appears to lie in the coordination and cooperation between government agencies and civil society. There is debate and conflict in the policies formed and how to support existing programs. As a result, programs seem to be inefficient and redundant because there is such a lack of change. More research should be done to see what is needed, to evaluate the current practices and make the necessary changes where applicable. There must be specific policies created and implemented to better coordinate the roles of the government and the division of labor when it comes to multiculturalism. Also, policy must be changed for children born in Korea to have the choice to become Korean citizens. More lobbying on behalf of immigrants and their children is needed to ensure all children of multicultural families receive an equal education.

Another great need is to help foreigners assimilate to Korean culture. Many foreign workers living and working here receive almost no support. This lack of government support and legal services are still continuing problems that foreigners face. There is immense discrimination and the government bears no responsibility for this. As a result, nonprofit organizations, and the civil society have to compensate for the lack of government support and limitation of funds that the government provides. Most multicultural schools receive little or no funding from the government. Some have received the initial set up fees to be established, but ongoing funding is nonexistent. As a consequence, most schools survive on the basis of donations and volunteer fundraising.

Funding is important but equally important is to teach both students in Korean public schools and students of multicultural schools how to coexist. Getting rid of stereotypes and biases can help relinquish any ill feelings towards each other and, only then, can doors be truly open for change. It is a matter of respect for people and a convergence of cultures that need to be emphasized. The government should provide the basic framework, but it is up to the local residents and local municipalities to embrace the diversity of Koreans. To alleviate tensions or misunderstandings, it is equally important for those new to Korea to get familiar and learn about Korean culture to appreciate their new residences. More publicity is needed for the current policies in 
place as well as knowledge of support organizations that exist. Most residents in Korea are not aware of the many organizations that are established to help support multiculturalism. Both Koreans and non-citizens have little knowledge of both the civil organizations and government policies.

In addition, there needs to be an awareness of multiculturalism and how it affects the Korean economy. Foreign workers here account for a significant portion of Korea's income and Koreans need to be aware that they are helping to develop the growth of the economy. The blending of cultures can add a significant vitality to Korean culture. Recognizing the contributions of foreigners can help promote Korea to a higher level in the international community.

There needs to be more integration rather than segregation. The concept of separate but equal leads to continuing stereotypes and prejudices. This system failed in the United States during the implementation of the Jim Crow Laws in the Southern United States where black students were separated from white students in every aspect of society. Korea should not strive to be a melting pot. Rather, it should work toward becoming more like a box of chocolates. Recognizing the strength that the diversity of its people provides, citizens and noncitizens alike, should coexist harmoniously together to live in a more truly global society.

Age

Appendix A
Grade__ Gender: Male/ Female

Ethnicity

\section{Circle YES or NO}

1. Would you like to attend a Korean public school? YES NO

2. Have you ever attended a Korean public school? YES NO

a. If yes, how were you treated by other students?

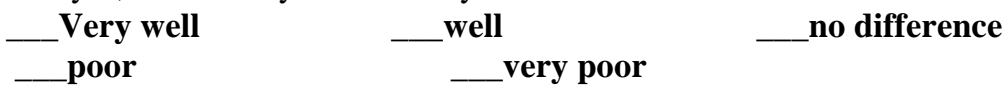

b. If yes, how were you treated by the staff and teachers at your school?

$\begin{array}{ll}\text { very well } & \text { well } \\ \text { poor } & \text { very poor }\end{array}$

3. Do you think multicultural students should attend Korean public schools? YES NO

4. Do you feel comfortable living in Korea? YES NO

5. Have you ever experienced discrimination? YES NO

\section{Multiple Choice Check all that apply.}

\section{How long have you lived in Korea?}

6 months or less
more than 5 (if more than 5, how many?

2. What languages do you speak? Check all that apply.

$\begin{array}{llll}\text { English } & \text { Korean } & \text { Vietnamese } & \text { Chinese } \\ \text { Tagalog } & \text { - Spanish } & \text { - Arabic } & \text { Hindi } \\ \text { Russian } & \text { _ French } & \text { Thai } & \text { Indonesian }\end{array}$

Other

3. Which of the following matches your definition of what it means to be a Korean?

born in Korea

raised in Korea

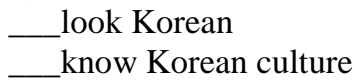

know Korean culture speak Korean

have Korean parents

4. What problems do multicultural children face living in Korea?

language

culture appearance

__
__ socio-economic background stereotypes 


\section{References}

[1]. Brannen, F. (April 13, 2013). The Movement for the Cultural-Diversity of Koreans. Presentation to Daeyoung High School. Seoul, Republic of Korea

[2]. Brannen, F. (May 28, 2013). Separate and Unequal. Session 4: Health, Education \& Welfare - Discussion. The 1st International Conference for the Development of Multiculturalism in Asia. Seoul, Republic of Korea.

[3]. Bring Your I.D. (May 18, 2013) A Forum of Mixed Koreans to help promote the social awareness of Koreans in Korea sponsored by ASK and M.A.C.K. Foundation, Seoul, South Korea

[4]. Cho, M. (July 19, 2012). Discrimination Against Multiracial Families. Retrieved March 20th, 2013 from http://www.humanrightskorea.org/2012/discrimination-against-multicultural-families-bi-ethnic-children-and-foreign-immigrantworkers/

[5]. Diggs-Yang, G.C. (April 12, 2013). The Movement for the Cultural Diversity of Koreans. Presentation to Sangil Girls High School. Seoul, Republic of Korea.

[6]. Han, Kook-Yum (2007). Statistics and Tasks of Migrant Foreigners: 'Human Rights in 2007.'Human Rights Report, pp.1-24. Seoul: Korean Association of Attorneys.International Organization for Migration (2013). Migration policy development in the Republic of Korea: A brief review of the Second Basic Plan for Immigration Policy (2013-2017. Retrieved March 31, 2014 from http://www.iom.int/cms/en/sites/iom/home/what-we-do/migration-policy-and-research/migration-policy-1/migration-policypractice/issues/october-november-2013/migration-policy-development-in.html

[7]. Jungsoon, C. (2010). Educating Citizens in a Multicultural Society: The Case of South Korea. Social Studies, 101(4), pp.174-178.

[8]. Kang-McCain, J. (May 1, 2013). Presentation at Amerasian Christian Academy. Duksung Women's University. Seoul, Republic of Korea.

[9]. Korea Goes Multicultural (May 8, 2012). Korea.net: Gateway to Korea. Retrieved March 31, 2013 from http://www.korea.net/NewsFocus/Society/view?articleId=100308.

[10]. Korean International Labor Foundation (March, 2013). 62,000 Foreign Workers Will Come to Korea in 2013. Retrieved from www.migrantok.org/english/portal.php?sid=d32a1a701a37fa334fe5d20d40d63f05

[11]. Kim, Y.W., (April 12, 2013). Korean Society Struggles to Embrace Multiculturalism, The Jakarta Post. Retrieved March 31st, 2013 from www.http://www.thejakartapost.com/news/2012/06/19/korean-society-struggles-embrace-multiculturalism.html

[12]. Korean Ministry of Public Administration and Security (2011) Survey of Multicultural Families. Retrieved October 14th, 2013 from www.mospa.go.kr

[13]. Korean Ministry of Education (April, 2013). Retrieved October 28th, 2013 from www.moe.go.kr. Press Release

[14]. Korean Ministry of Education (March,2012). Press BriefingPress Release, Itaewon Middle School, Seoul, South Korea.

[15]. Constitution of the Republic of Korea (July 12, 1948). Retrieved April 13th, 2014 from www.english.cc.go.kr.

[16]. Lee, Woo-Young ( March 12, 2012). Korea To Support Multicultural Children ,The Korea Herald, Seoul, South Korea.

[17]. Lee, Nam Chul \& Lee, Mi Yeong. (September 22, 2011). Human resources development of children of international marriage households and foreign workers in Korea The Free Library. (2011). Retrieved March 16, 2013 from http://www.thefreelibrary.com/Human resources development of children of international marriage...-a0299759795

[18]. Kong, D., Yoon, K., \& Yu, S. (2010). The Social Dimensions of Immigration in Korea. Journal of Contemporary Asia, 40(2), $\begin{array}{lllll}\text { pp.252-274. April } & \text { 26th, } & 2013\end{array}$ from $\quad$ http://av4kc7fg4g.search.serialssolutions.com.ezproxy.apollolibrary.com/?ctx ver $\quad=Z 39.88-$ $2004 \&$ ctx enc=info\%3Aofi\%2Fenc\%3AUTF-

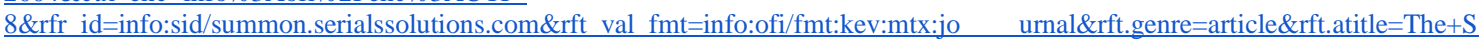
ocial+Dimensions+of+Immigration+in+Kor ea\&rft.jtitle=Journal+of+Contemporary+Asia\&rft.au=Kong\%2C+Dongsung\&rft.a $\mathrm{u} \quad=$ Yoon\%2C+Kiwoong\&rft.au=Yu\%2C+Soyung\&rft.date=2010-05- $\quad 01 \& r f t . i s s n=0047-2336 \& r f t . e i s s n=1752-$ $7554 \&$ rft.volume $=40 \&$ rft.issue $=2 \&$ rft.spage $=252 \&$ rft.epage $=274 \&$ rft id $=$ info: $:$ doi $/ 1$ $0.1080 \% 2 F 00472331003600473 \&$ rft.externalDBID=n\%2Fa\&rft.externalDocID $=10 \quad 108000472331003600473$

[19]. MacLellan, D. \& Brannen, F. (March 18, 2013). Survey: "Multicultural Students'. Life in Korea".

[20]. Ministry of Justice (October, 2010). Enforcement Decree on the Primary and Secondary Education Act. Retrieved November 11, 2013 from www.moj.go.kr.

[21]. Ministry of Justice (January, 2012) Foreign Born Population. Retrieved January 14, 2014 from www.moj.go.ko

[22]. Ministry of Justice (December, 2011). Foreign National in Korea. Retrieved November 11th, 2013.

[23]. Kang, T.J. (August 20, 2013). Korea's Multicultural Growing Pains, The Diplomat. Retrieved November 11th, 2013 from www.http://thediplomat.com/2013/08/koreas-multicultural-growing-pains/

[24]. National Center on Education and the Economy(NCEE) (2012).Instructional Systems, Center on International Education Benchmarking. Retrieved June 12, 2013 from http://www.ncee.org/programs-affiliates/center-on-international-educationbenchmarking/top-performing-countries/south-korea-overview/south-korea-instructional-systems/

[25]. National Center on Education and the Economy(NCEE) (2012) System and School Organization, Center on International Education Benchmarking. Retrieved June 12, 2013 from http://www.ncee.org/programs-affiliates/center-on-international-educationbenchmarking/top-performing-countries/south-korea-overview/south-korea-system-and-school-organization/

[26]. National Human Rights Commission Korea (2010). Study of the Status of Educational Rights of Migrant Children. Retrieved April 2nd, 2013 from www.humanrights.go.kr National Human Rights Commission Korea (2010). Section 21: Recommendation to Improve the Rights of Migrant Children to Education. Retrieved April 2nd, 2014 from www.humanrights.go.kr

[27]. OECD (2013) International Migration Outlook 2013, OECD Publishing, http://dx.doi.org/10.1787/migr_outlook-2013-en

[28]. Oaten, J. (November 23, 2012). Homogenous Korea Yet to Discover Multiculturalism. The World Today. Retrieved March 31, http://www.abc.net.au/worldtoday/content/2012/s3639394.htm

[29]. Olneck, M. R. (2011). Facing Multiculturalism's Challenges in Korean Education and Society. Asia Pacific Education Review, 12(4), pp.675-690. Retrieved April 26th, 2013 from ProQuest Database.

[30]. Paving the Future of Multicultural Asia (May 27-29, 2013). The 1st International Conference for the Development of Multiculturalism in Asia. National Assembly, Seoul, South Korea.

[31]. Park, JiSu, (July 2, 2012). Children of Multicultural Families Quit School. Retrieved November 11, 2013 from www.humanrightskorea.org/2012/children-of-multicultural-families-in-south-korea-quit-school/

[32]. Seol, D. (2010). Which Multiculturalism? Discourse of the Incorporation of Immigrants into Korean Society. Korea Observer, 41(4), pp.593-614. Retrieved from http://search.proquest.com/docview/837429523?accountid=35812

[33]. Soon-Won, K. (2010). Multicultural Education and the Rights to Education of Migrant Children in South Korea. Educational Review, 62(3), pp.287-300. 
[34]. Watson, S.L., Park, G.C, \& als (December 1 $1^{\text {st }}$, 2011). Reading Level (Lexile):1490. International Journal of Education, Retrieved April 26th, 2013 from $\quad$ http://av4kc7fg4g.search.serialssolutions.com.ezproxy.apollolibrary.com/?ctx ver $=$ Z39.88-2004\&ctx enc=info\%3Aofi \%2Fenc\%3AUTF-

8\&rfr_id=info:sid/summon.serialssolutions.com\&rft val fmt=info:ofi/fmt:kev:mtx:jo urnal\&rft.genre=article\&rft.atitle=P re-service+teachers $\% 27+$ awareness+and+attitudes+on+South+Korea $\% 27 \mathrm{~s}+$ increa

sing+cultural+and+ethnic+diversity+and+the+role+of+multicultural+education+in

$12+$ schools\&rft.jtitle=International+Journal+of+Education\&rft.au=Watson $\% 2 \mathrm{C}+\mathrm{Su}$

nnie+Lee\&rft.au=Park\%2C+Gilbert+C\&rft.au=Lee\%2C+Hong-Soo\&rft.date=2011-12-

$01 \&$ rft.pub $=$ Macrothink+Institute\%2C+Inc\&rft.issn=1948- $\quad$ 5476\&rft.eissn=1948-

5476\&rft.volume=3\&rft.issue=2\&rft.externalDBID=n\%2Fa\&rft.externalDocID=280 719751 . $+\mathrm{K}-$

[35]. Watson, I. (2010). Multiculturalism in South Korea: A Critical Assessment. Journal of Contemporary Asia, 40(2), pp.337-346. Doi: $10.1080 / 00472331003600549$

[36]. Won-Pyo, H.(January 9th, 2010). Multicultural Education in Korea: It's Development, Remaining issues, and Global Implications. Asia Pacific Education Review, 11(3), DOI: 10.1007/s12564-010-9089-x, Springer Netherlands.

[37]. Yang, K. (January 18, 2012). Korea's Multicultural Policy and Local Governance. International Symposium: Korean Embassy, Japan.

[38]. Yang, C. (March 10, 2013) Caught Between Hong Kong's' Two Systems. Retrieved March $23^{\text {rd }}$, 2013 from www.nytimes.com/2013/03/11/world/asia/caught-between-hong-kongs-two-

systems.html?pagewanted $=1 \&$ r $=2 \&$ ref=internationaleducation 